\title{
First report on Babesia cf. microti infection of red foxes (Vulpes vulpes) from Hungary
}

\author{
Róbert Farkas ${ }^{1 *}$, Nóra Takács', Ákos Hornyák², Yaarit Nachum-Biala Sándor Hornok and Gad Baneth ${ }^{3}$
}

\begin{abstract}
Background: To date, only one report of a small Babesia infection based on microscopic observation which caused babesiosis in two dogs in Hungary has been published. Babesiosis due to Babesia canis - which is endemic in the local dogs - has only been detected in captive grey wolves. No information is available on babesial/theilerial infections in red foxes in Hungary. The aim of the study was to screen red foxes in Hungary for babesial parasites by PCR and to compare their partial 18S rRNA gene sequences to those parasites of domestic dogs and wild canids from other countries.

Methods: Blood samples of 404 red foxes originating from 316 locations representing all 19 Hungarian counties were screened in Hungary for babesial parasites by PCR and the partial 185 rRNA gene sequences were compared to those parasites of domestic dogs and wild canids from other countries.

Results: Altogether 81 red foxes out of 404 (20.0\%; 95\% Cl: 16.4-24.2\%) shot in 74 locations and in 17 of the 19 Hungarian counties were found to be infected with Babesia cf. microti by PCR.

Conclusions: This is the first report to demonstrate the occurrence of Babesia cf. microti in Hungary, and its widespread presence in the fox population throughout the country. Further studies are needed to identify the tick species involved in its transmission, and whether other mechanisms of transmission are involved in its spread in fox populations.
\end{abstract}

Keywords: Red fox, Vulpes vulpes, Theileria annae, Babesia cf. microti, Hungary

\section{Background}

Tick-borne piroplasmoses, caused by several intraerythrocytic apicomplexan protozoa, occur in a wide variety of vertebrates worldwide. Morphologically distinct large and small babesiae cause canine babesiosis in many parts of the world [1]. For many decades it was assumed that Babesia canis and Babesia gibsoni cause disease in dogs, and all small babesiae found in dogs were considered as B. gibsoni [2]. The genetic analyses of small babesiae of dogs have revealed that B. gibsoni, Babesia conradae, and the Babesia cf. microti species are phylogenetically close to zoonotic B. microti of rodents [3-5]. Zahler et al. [6] were the first to describe Babesia cf. microti infection from a German dog which had clinical babesiosis characterized by lethargy, fever, and anaemia after arriving back from Spain, and they proposed the name Theileria annae for the piroplasm. The Babesia cf. microti species is also referred to as the "Spanish dog isolate" [1,7]. Babesia cf.

\footnotetext{
* Correspondence: Farkas.Robert@aotk.szie.hu

${ }^{1}$ Department of Parasitology and Zoology, Faculty of Veterinary Science,

Szent István University, Budapest, Hungary

Full list of author information is available at the end of the article
}

microti infection was reported to be hyperendemic in Galicia, northwestern Spain, and was detected in 157 local dogs belonging to different breeds, coming from both urban and rural areas [8]. Infection with the \#Babesia cf. microti caused disease associated with severe haemolysis, intense regenerative haemolytic anaemia, thrombocytopenia and azotaemia related to renal failure which was the main cause of death implicated in Spanish dogs [9-11]. A few years later Yeagley et al. [7] first reported that this organism also occurred in a dog in North America when one out of 157 dogs was positive for the canine small Babesia 'Spanish isolate'. Babesia cf. microti parasites have also been detected in dogs from Croatia [12] and Portugal [13].

With regard to fox infection, Criado-Fornelio et al. [4] reported that they detected Babesia cf. microti DNA in 5 red foxes when studying frozen DNA samples obtained from the spleen of 10 foxes captured in central Spain during 1997-1999. A BLAST search in GenBank revealed $100 \%$ similarity of Spanish red fox (Vulpes vulpes) isolate sequence and T. annae found in dogs. Further studies confirmed that the occurrence of this small 
protozoan is not uncommon in foxes in Spain which seemed to be an important wild reservoir of this pathogen [14-16]. Babesia cf. microti or T. annae has also been detected in foxes from other European countries, such as Italy [17-19], Croatia [20] Portugal [21] and Germany [22] and Austria [23]. A genetically and morphologically similar parasite has also been identified in foxes from North America [24,25]. When partial $18 \mathrm{~S}$ ribosomal ribonucleic acid and beta tubulin gene sequences of the North American parasites detected from red fox (Vulpes vulpes) and gray fox (Urocyon cinereoargenteus) samples from Canada and the USA were analysed they were nearly identical to those ones previously reported from American foxes and Spanish dogs [26]. The tick vector species which transmits Babesia cf. microti is currently unknown. Camacho et al. [27] hypothesized that the European hedgehog tick Ixodes hexagonus could be the main candidate vector based on the higher prevalence of this tick species on dogs infected with this small Babesia, however this hasn't been proven.

Canine babesiosis caused by the large Babesia species, B. canis is endemic in Hungary $[28,29]$. To date, only one report of a small Babesia infection based on microscopic observation which caused babesiosis in two dogs in Hungary has been published [30]. Among wild canids, babesiosis due to $B$. canis has only been detected in captive grey wolves (Canis lupus) [31]. To our knowledge, no information is available on babesial/theilerial infections in red foxes in Hungary. Therefore, the purpose of this study was to screen red foxes in Hungary for babesial parasites by PCR and to compare their partial $18 \mathrm{~S}$ rRNA gene sequences to those parasites of domestic dogs and wild canids from other countries.

\section{Methods}

\section{Collection of samples}

Blood samples were collected from 404 red foxes originating from 316 locations representing all 19 Hungarian counties between June and October 2011 (Figure 1). The foxes were shot and the carcasses were sent to the Veterinary Diagnostic Directorate, National Food Chain Safety Office, Budapest, as part of a control program on oral immunization of foxes against rabies. After opening the thoracic cavity of foxes, blood samples were obtained via cardiac puncture from the right atrium or chest cavity and were then frozen at $-20^{\circ} \mathrm{C}$ until further processing. Gender of foxes was not recorded.

\section{Ethical approval}

The study was carried out in compliance with the ethical guidelines for study of wildlife animals in Hungary, and in agreement with the national animal welfare regulations (28/1998), and was approved by the Ethics Committee of the Faculty of Veterinary Science (SZIU).

\section{DNA isolation, amplification and sequencing}

DNA was extracted from each blood sample using the QIAamp DNA Mini Kit (QIAgen GmbH., Hilden, Germany) following the "Blood and body fluid" protocol instructions by the manufacturer. A conventional single step PCR was used to amplify a 487 bp long fragment of the $18 \mathrm{~S}$ rRNA gene of piroplasms with primers BJ1 [5'GTC TTG TAA TTG GAA TGA TGG-3'] and BN2 [5'TAG TTT ATG GTT AGG ACT ACG-3'] [32]. Reaction mix contained $15.9 \mu \mathrm{l}$ sterile deionized water, $2.5 \mu \mathrm{l}$ of $10 \times$ concentration of CoralLoad Buffer (15 mM $\mathrm{MgCl}_{2}$ included), $0.5 \mu \mathrm{l} 10 \mathrm{mM} \mathrm{dNTP}, 0.5 \mu \mathrm{l}$ of each primer $(50 \mu \mathrm{M})$ and $0.1 \mu \mathrm{l}(5 \mathrm{U} / \mu \mathrm{l})$ of HotStarTaq Plus DNA Polymerase in a final volume of $25 \mu \mathrm{l}$ containing $5 \mu \mathrm{l}$ DNA. Amplification was performed with a BIOER GenePro BIOER TC-E-BD device (Bioer, Hangzhou, PR China). Initial denaturation at $95^{\circ} \mathrm{C}$ for 10 minutes was followed by 40 cycles of denaturation at $95^{\circ} \mathrm{C}$ for $30 \mathrm{~s}$, annealing at $54^{\circ} \mathrm{C}$ for $30 \mathrm{~s}$ and elongation at $72^{\circ} \mathrm{C}$ for $40 \mathrm{~s}$. The thermal program was finished with 5 minutes of final elongation at $72^{\circ} \mathrm{C}$. Selected PCR products were purified and sequenced by Biomi Inc. (Gödöllő, Hungary).

\section{Phylogenetic analysis}

A phylogenetic analysis, which included DNA sequences from foxes from this study, was carried out to compare these sequences to other Babesia spp. sequences deposited in GenBank ${ }^{\circ}$. Hepatozoon canis sequences were used as an outgroup [33]. Sequences were analyzed using the MEGA version 6.06 (http://www.megasoftware.net) and a phylogenetic tree was constructed by the Maximum likelihood algorithms using the Tamura 3-Parameter model. Bootstrap replicates were performed to estimate the node reliability, and values were obtained from 500 randomly selected samples of the aligned sequence data.

\section{Statistical analysis}

Confidence intervals (CI) for the prevalence rates were calculated at the level of $95 \%$.

\section{Results}

Altogether 81 red foxes out of 404 (20.0\%; 95\% CI: 16.4$24.2 \%$ ) were found to be infected with piroplasms by PCR. The positive animals were shot in 74 locations and in 17 of the 19 Hungarian counties except for Nógrád and Heves located in the northern part of the country close to Slovakia (Figure 1). When the $18 \mathrm{~s}$ RNA gene fragments from 30 positive foxes from 17 counties were sequenced and compared by BLAST with 18S rRNA sequences of Babesia and Theileria spp. available in GenBank, only Babesia cf. microti was detected. BLAST search revealed that all the submitted representative sequences obtained from 14 Hungarian foxes to GenBank (GenBank accession no. KM232509-22) were 100\% identical to 


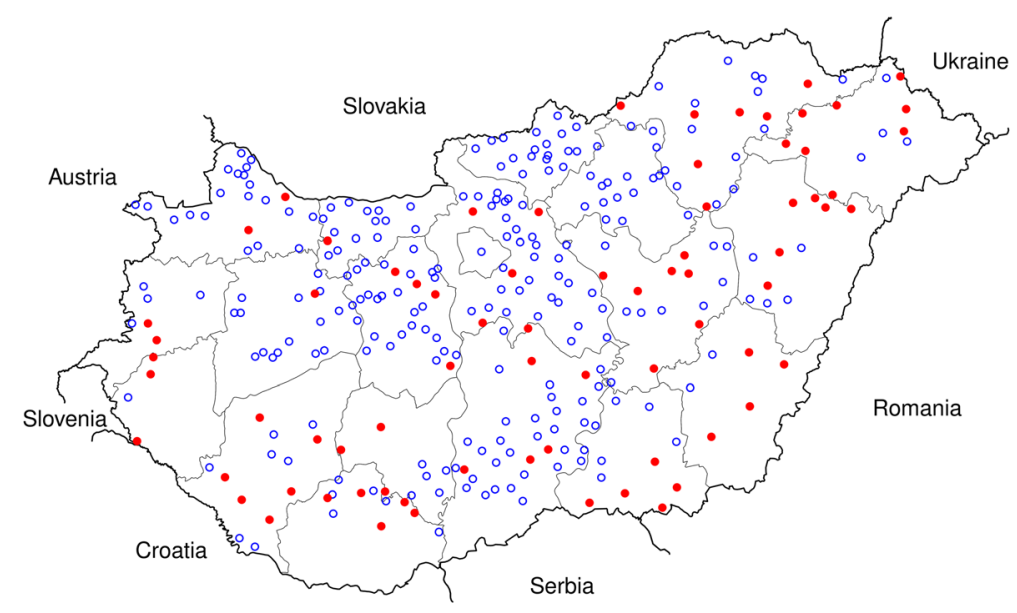

Figure 1 The sampling sites of red foxes and where (red dots) foxes were found to be infected with Babesia cf. microti parasites in Hungary.

B. microti-like from a fox in Croatia (GenBank accession no. HM212628.1) as well as to other B. microti-like sequences from Italy (GenBank accession no. KF773740.1) and from I. hexagonus ticks found on a German red fox (GenBank accession no. JX679168.1).

A Maximum likelihood phylogenetic tree based on $392 \mathrm{bp}$ from the 18S rRNA gene indicated that sequences from foxes tested in this study clustered together with other sequences of Babesia cf. microti or T. annae and separately from other piroplasmids including other Babesia spp. that infect canids (Figure 2).

\section{Discussion}

The complete identity of Babesia cf. microti sequences detected from foxes in Hungary with Babesia cf. microti found in a fox in Croatia [20] allows us to suggest that Babesia cf. microti may have been introduced into Hungary from this neighbouring country. However, it cannot be excluded that this protozoan was transmitted from Hungary to Croatia by infected foxes. The occurrence of this blood parasite has been reported from another country neighbouring Hungary [23]; therefore, the parasite may have been introduced also from there. The fact that this protozoan parasite is widespread in the Hungarian fox population suggests that it was not recently introduced. The prevalence of Babesia cf. microti infection found in foxes in this study (20\%) is higher than the prevalence of another tick-borne protozoan, Hepatozoon canis, recently described in red foxes in Hungary with a prevalence of $8 \%$. Unlike Babesia cf. microti, $H$. canis is suspected to have been more recently introduced into Hungary, possibly from Croatia (33). The tick $I$. hexagonus suggested as the vector of $T$. annae in Spain [27] is known to be present in Central Europe [34], and also in Hungary [35]. According to the findings of an earlier Hungarian survey, $I$. hexagonus very rarely occurred among the 2500 ticks found on foxes [36], in contrast to the findings of a survey conducted in Germany where almost one-quarter of the 1953 ticks collected from foxes belonged to the species I. hexagonus [22]. In our opinion, although $I$. hexagonus may be the vector of this small piroplasm, involvement of other tick species in its transmission cannot be excluded. The latter possibility is supported by the fact that Babesia cf. microti occurs also in countries where $I$. hexagonus is either absent or uncommon [26]. According to German researchers [22], I. ricinus and I. canisuga may also act as a vector for $T$. annae, as ticks belonging to these species were often found on infected foxes. However, Babesia cf. microti DNA has been detected in $I$. ricinus as well as in $R$. sanguineus in Italy [37,38] and Spain [16] and I. canisuga in Germany [22]. The above-mentioned studies included ticks that have fed on foxes and therefore, being positive by PCR for the parasite might only signify that the blood meal contained its DNA, and not necessarily that the ticks are competent vectors in which the parasite can commence its life cycle. Therefore, further research is needed to clarify whether these tick species have vector competence for transmitting Babesia cf. microti. It is also possible that non-vectorial pathways of transmission may be responsible for the wide distribution of Babesia cf. microti in Hungary. According to Portuguese [13] and Swedish [39] researchers, this parasite may be capable of vertical spread and intrauterine transmission to the fetus, as its occurrence has been demonstrated in puppies free of tick infestation. It has also been suggested that, like B. gibsoni [40], Babesia cf. microti piroplasms can be transmitted among animals through bite wounds $[7,26]$. 


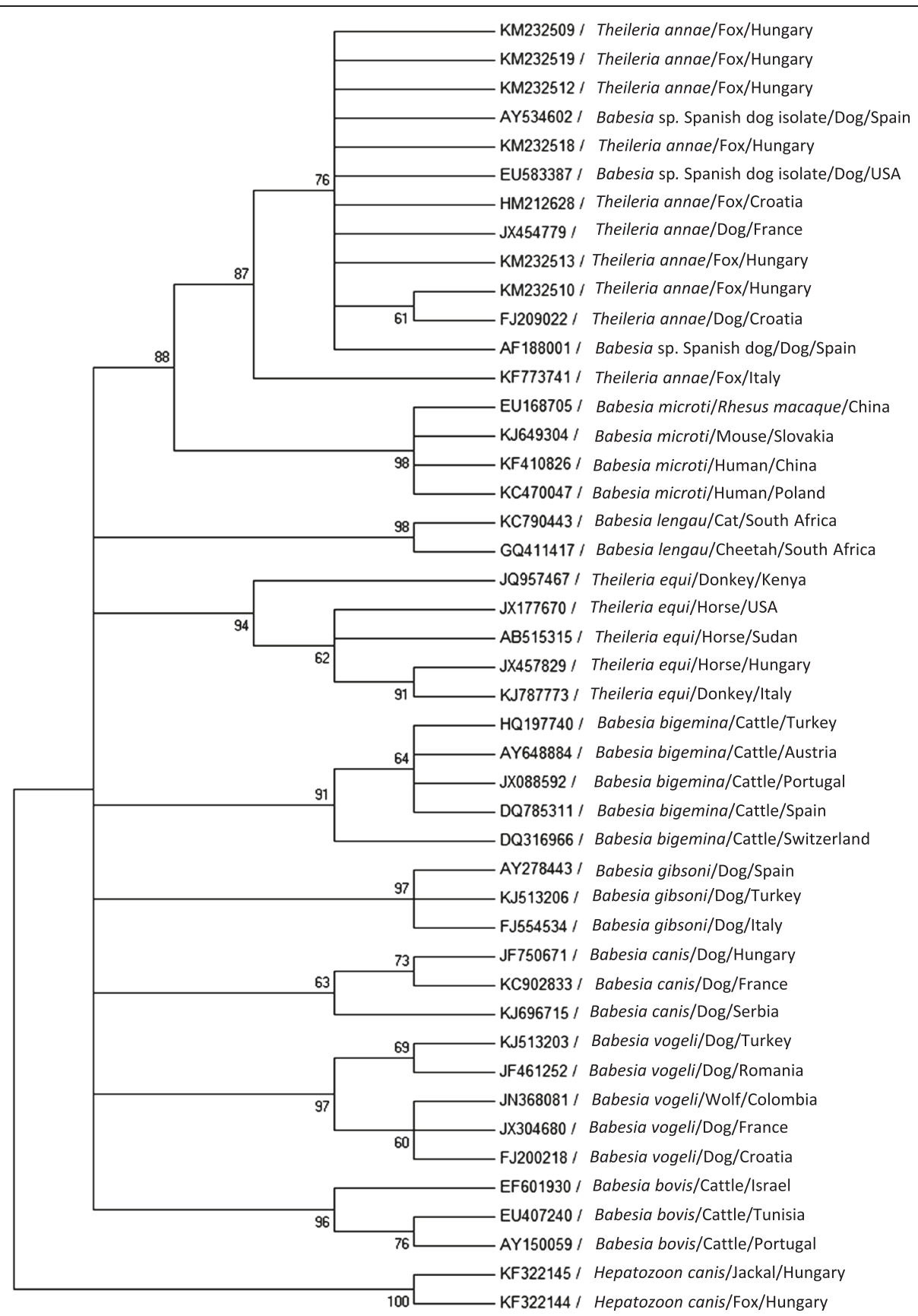

Figure 2 Maximum likelihood 18S tree; A Maximum likelihood tree phylogram comparing 392 bp 18S DNA Babesia cf. microti (Theileria annae) sequences from Hungary included in this study to other Babesia and Theileria spp. sequences deposited in GenBank ${ }^{\circledR}$. Hepatozoon canis sequences were used as an outgroup. The GenBank accession numbers, animal host species and country of origin from which the sequences were derived are included for each sequence. All six T. annae GenBank accesions from Hungary included in the phylogram are derived from foxes included in the current study.

Further studies are needed to determine whether this parasite species can cause disease in foxes in the same way as it does in dogs. So far, there has been only a single report on clinical signs caused by T. annae in a fox [25]. In view of the widespread and common infection of foxes [22], we presume that this parasite is not pathogenic to foxes, and that foxes only act as its reservoir. Another question that remains to be answered is whether the golden jackal (Canis aureus), a wild canine species with a south to north range expansion in Hungary [41], can be a reservoir of this parasite. The parasite can probably be transmitted from foxes to dogs by ticks; however, currently 
no massive outbreaks such as those reported from Spain have occurred $[8,10,11]$. In Hungary, babesiosis caused by small babesiae has hitherto been demonstrated only in two dogs [30]; however, the species could not be identified by microscopic examination, as genetic analysis of the parasite was not possible. It has long been known that $B$. canis, a species causing severe disease in dogs, is present throughout Hungary $[28,29]$; therefore, the question arises whether or not the immune response and seropositivity of dogs to this species would prevent the development of clinical signs caused by Babesia cf. microti piroplasms. We have not had any knowledge whether detectable antibodies to this piroplasm species are produced in the foxes or in the affected dogs. It also requires explanation why $B$. canis did not occur in any of the several hundred foxes included in the study, when previous studies have demonstrated that the tick $D$. reticulatus transovarially transmitting this protozoon is a common ectoparasite of foxes [36]. Infection of red foxes with $B$. canis has been previously reported, but the parasite was identified only by microscopic examination [42]. During studies conducted in Croatia [20], B. canis was not detected in foxes even by molecular methods, although canine babesiosis caused by this blood parasite is also known to be common in that country [12]. Recently, Portuguese authors have reported, for the first time, the detection of $B$. canis infection by PCR in only one out of 91 red foxes examined [21]. In spite of the studies published on this parasite so far, our knowledge of its effect on the animal host's health is insufficient, and it is not known whether this parasite has strains of different virulence. According to the studies conducted to date, the host range of Babesia cf. microti extends beyond domestic and free-living carnivores, as this parasite has been detected also from other animal species including the horse [17], donkey [15], and cat [14]; however, its ability to induce disease in these latter species is unknown. In addition to the need to identify the tick species involved in transmitting the parasite, it remains to be determined whether ticks transmit this parasite only transstadially, as is the case with $B$. microti [43], or also transovarially, thus ensuring its survival and spread of in multiple tick generations.

\section{Conclusions}

In summary, this is the first report to demonstrate the occurrence of Babesia cf. microti in Hungary, and its widespread presence in the fox population throughout the country. Further studies are needed to identify the tick species involved in its transmission, and the parasite's mechanisms of transmission.

\section{Competing interests}

The authors declare that they have no competing interests.

\section{Authors' contributions}

Designed the study: RF, SH, GB. Collected samples: RF, SH, ÁH. Processed samples: RF, NT, ÁH. Performed PCR: NT, YNB. Analyzed sequences: RF, GB, NT, YNB. Analyzed the data: RF, NS. Wrote the paper: RF, GB. All authors read and approved the final version of the manuscript.

\section{Acknowledgments}

The authors are grateful to Mónika Gyurkovszky (Faculty of Veterinary Science, Budapest) for helping in laboratory work and Norbert Solymosi for preparing the map of Figure 1. This study was partially funded by the European Union grant FP7-261504 EDENext and is catalogued by the EDENext Steering Committee as EDENext293 (www.edenext.eu). The contents of this publication are the sole responsibility of the authors and do not necessarily reflect the views of the European Commission. The authors thank the European Cooperation in Science and Technology (COST) action TD1303 EURNEGVEC.

\section{Author details}

${ }^{1}$ Department of Parasitology and Zoology, Faculty of Veterinary Science, Szent István University, Budapest, Hungary. ${ }^{2}$ Veterinary Diagnostic Directorate, National Food Chain Safety Office, Budapest, Hungary. ${ }^{3}$ School of Veterinary Medicine, Hebrew University of Jerusalem, Jerusalem, Israel.

Received: 12 November 2014 Accepted: 13 January 2015

Published online: 27 January 2015

\section{References}

1. Irwin P. Canine babesiosis: from molecular taxonomy to control. Parasites Vect. 2009;2 Suppl 1:S4

2. Boozer AL, Macintire DK. Canine babesiosis. Vet Clin North Am Small Anim Pract. 2003:33:885-904.

3. Kjemtrup AM, Kocan AA, Whitworth L, Meinkoth J, Birkenheuer AJ, Cummings J, et al. There are at least three genetically distinct small piroplasms from dogs. Int J Parasitol. 2000;30:1501-5.

4. Criado-Fornelio A, Martinez-Marcos A, Bulin-Sarana A, Barba-Carretero JC. Molecular studies on Babesia, Theileria and Hepatozoon in southern Europe. Part I. Epizootiological aspects. Vet Parasitol. 2003;113:189-201.

5. Matjila PT, Leisewitz AL, Oosthuizen MC, Jongejan F, Penzhorn BL. Detection of a Theileria species in dogs in South Africa. Vet Parasitol. 2008;157:34-40.

6. Zahler M, Rinder $\mathrm{H}$, Schein $\mathrm{E}$, Gothe R. Detection of a new pathogenic Babesia microti-like species in dogs. Vet Parasitol. 2000;89:241-8.

7. Yeagley TJ, Reichard MV, Hempstead JE, Allen KE, Parsons LM, White MA, et al. Detection of Babesia gibsoni and the canine small Babesia 'Spanish isolate' in blood samples obtained from dogs confiscated from dogfighting operations. J Am Vet Med Assoc. 2009;235:535-9.

8. Camacho AT, Pallas E, Gestal JJ, Guitián FJ, Olmeda AS, Goethert HK, et al. Infection of dogs in northwest Spain with a Babesia microti-like agent. Vet Rec. 2001;149:552-5.

9. Guitián FJ, Camacho AT, Telford III SR. Case-control study of canine infection by a newly recognised Babesia microti-like piroplasm. Prev Vet Med. 2003;61:137-45.

10. Camacho AT, Guitian EJ, Pallas E, Gestal JJ, Olmeda AS, Goethert HK, et al. Azotemia and mortality among Babesia microti-like infected dogs. J Vet Intern Med. 2004;18:141-6.

11. Camacho-García AT. Piroplasma infection in dogs in northern Spain. Vet Parasitol. 2006;138:97-102.

12. Beck R, Vojta L, Mrljak V, Marinculić A, Beck A, Živičnjak T, et al. Diversity of Babesia and Theileria species in symptomatic and asymptomatic dogs in Croatia. Int J Parasitol. 2009;39:843-8.

13. Simões PB, Cardoso L, Araújo M, Yisaschar-Mekuzas Y, Baneth G. Babesiosis due to the canine Babesia microti-like small piroplasm in dogs - first report from Portugal and possible vertical transmission. Parasites Vect. 2011;4:50.

14. Criado-Fornelio A, Rey-Valeiron C, Buling A, Barba-Carretero JC, Jefferies R, Irwin P. New advances in molecular epizootiology of canine hematic protozoa from Venezuela, Thailand and Spain. Vet Parasitol. 2007;144:261-9.

15. Gimenez C, Casado N, Criado-Fornelio A, de Miguel FA, Dominguez-Peñafiel G. Molecular survey of Piroplasmida and Hepatozoon isolated from domestic and wild animals in Burgos (northern Spain). Vet Parasitol. 2009;162:47-50.

16. Lledó L, Giménez-Pardo C, Domínguez-Peñafiel G, Sousa R, Gegúndez MI, Casado N, et al. Molecular detection of hemoprotozoa and Rickettsia species in arthropods collected from wild animals in the Burgos Province, Spain. Vector Borne Zoonotic Dis. 2010;10:735-8. 
17. Pietrobelli M, Cancrini G, Moretti A, Tampieri MP. Animal babesiosis: an emerging zoonosis in Italy? Parassitologia. 2007;49(S1):33-8.

18. Tampieri MP, Galuppi R, Bonoli C, Cancrini G, Moretti A, Pietrobelli M. Wild ungulates as Babesia hosts in northern and central Italy. Vector-Borne Zoonot. 2008;8(5):667-74.

19. Zanet S, Trisciuoglio A, Bottero E, de Mera IG F, Gortazar C, Carpignano MG, et al. Piroplasmosis in wildlife: Babesia and Theileria affecting free-ranging ungulates and carnivores in the Italian Alps. Parasites Vect. 2014;7:70.

20. Dezdek D, Vojta L, Curković S, Lipej Z, Mihaljević Z, Cvetnić Z, et al. Molecular detection of Theileria annae and Hepatozoon canis in foxes (Vulpes vulpes) in Croatia. Vet Parasitol. 2010;172:333-6.

21. Cardoso L, Cortes HC, Reis A, Rodrigues P, Simões M, Lopes AP, et al. Prevalence of Babesia microti-like infection in red foxes (Vulpes vulpes) from Portugal. Vet Parasitol. 2013;196(1-2):90-5.

22. Najm NA, Meyer-Kayser E, Hoffmann L, Herb I, Fensterer V, Pfister K, et al. A molecular survey of Babesia spp. and Theileria spp. in red foxes (Vulpes vulpes) and their ticks from Thuringia, Germany. Ticks Tick Borne Dis. 2014;5(4):386-91.

23. Duscher $G G$, Hans-Peter Fuehrer $H$, Kübber-Heiss A. Fox on the run - molecular surveillance of fox blood and tissue for the occurrence of tick-borne pathogens in Austria. Short Report. Parasites Vect. 2014;7:521.

24. Goethert HK, Telford III SR. What is Babesia microti? Parasitology. 2003;127(Pt 4):301-9.

25. Clancey N, Horney B, Burton S, Birkenheuer A, McBurney S, Tefft K. Babesia (Theileria) annae in a red fox (Vulpes vulpes) from Prince Edward Island Canada. J Wild Dis. 2010;46(2):615-21.

26. Birkenheuer AJ, Horney B, Bailey M, Scott M, Sherbert B, Catto V, et al. Babesia microti-like infections are prevalent in North American foxes. Vet Parasitol. 2010;172:179-82.

27. Camacho AT, Pallas E, Gestal JJ, Guitián FJ, Olmeda AS, Telford III SR, et al. Ixodes hexagonus is the main candidate as vector of Theileria annae in northwest Spain. Vet Parasitol. 2003;112:157-63.

28. Földvári $G$, Hell E, Farkas R. Babesia canis canis in dogs from Hungary: detection by PCR and sequencing. Vet Parasitol. 2005;127:221-6.

29. Hornok S, Edelhofer R, Farkas R. Seroprevalence of canine babesiosis in Hungary suggesting breed predisposition. Parasitol Res. 2006;99:638-42.

30. Farkas R, Földvári G, Fenyves B, Szilágyi A, Kótai I, Hegedűs GYT. First detection of small babesiae in dogs in Hungary. Vet Rec. 2004;154:176-8.

31. Erdélyi K, Mezősi L, Vladov S, Földvári G. Fatal acute babesiosis in captive grey wolves (Canis lupus) due to Babesia canis. Ticks Tick Borne Dis. 2014;5(3):281-3.

32. Casati S, Sager H, Gern L, Piffaretti JC. Presence of potentially pathogenic Babesia sp. for human in Ixodes ricinus in Switzerland. Ann Agric Environ Med. 2006;13:65-70.

33. Farkas R, Solymosi N, Takács N, Hornyák Á, Hornok S, Nachum-Biala Y, et al. First molecular evidence of Hepatozoon canis infection in red foxes and golden jackals from Hungary. Parasites Vect. 2014;7:303.

34. Hillyard PD. Ticks of North-West Europe. London. UK: Backhuys Publishers; 1996. p. 178.

35. Babos S: Kullancsok - Ixodidea. Fauna Hungariae 77. XVIII. kötet, Arachnoidea 7. füzet. Akadémia Kiadó, Budapest 1965, 38 pp.

36. Sréter T, Széll Z, Varga I. Ectoparasite infestations of red foxes (Vulpes vulpes) in Hungary. Vet Parasitol. 2003;115:349-54.

37. Cassini R, Zanutto S, Frangipane del Rogalbono A, Gabrielli S, Calderini P, Moretti A, et al. Canine piroplasmosis in Italy: epidemiological aspects in vertebrate and invertebrate hosts. Vet Parasitol. 2009;165:30-5.

38. Iori A, Gabrielli S, Calderini P, Moretti A, Pietrobelli M, Tampieri MP, et al. Tick reservoirs for piroplasms in central and northern Italy. Vet Parasitol. 2010;170:291-6.

39. Falkenö U, Tasker S, Osterman-Lind E, Tvedten HW. Theileria annae in a young Swedish dog. Case report. Acta Vet Scand. 2013;55:50.

40. Matsuu A, Kawabe A, Koshida Y, Ikadai H, Okano S, Higuchi S. Incidence of canine Babesia gibsoni infection and subclinical infection among Tosa dogs in Aomori Prefecture. Japan. J Vet Med Sci. 2004;66:893-7.
41. Szabó L, Heltai M, Szűcs E, Lanszki J, Lehoczki R. Expansion range of the golden jackal in Hungary between 1997 and 2006. Mammalia. 2009;73:307-11.

42. Schoop G, Dedié K. Uebertragung von Babesia canis auf Füchse. Deut Tierärtzl Wochschr. 1938:46:88-90.

43. Gray J, Stedingk LV, Gürtelschmid M, Granström M. Transmission studies of Babesia microti in Ixodes ricinus ticks and gerbils. J Clin Microbiol. 2002;40(4):1259-63.

\section{Submit your next manuscript to BioMed Central and take full advantage of:}

- Convenient online submission

- Thorough peer review

- No space constraints or color figure charges

- Immediate publication on acceptance

- Inclusion in PubMed, CAS, Scopus and Google Scholar

- Research which is freely available for redistribution 